\title{
THE IMPACTS OF FORMULATION AND STORAGE ON $\alpha$-GLUCOSIDASE INHIBITORY ACTIVITY OF LEMONGRASS, GINGER, AND BLACK TEA FUNCTIONAL BEVERAGES
}

\section{Filiana Santoso, Jennifer Sunardi, Florence Ignatia, Maria Dewi Puspitasari Tirtaningtyas Gunawan-Puteri*)}

Faculty of Life Sciences and Technology, Swiss German University, Tangerang, Indonesia

Received June 8, 2020; Accepted January 19, 2021

\begin{abstract}
Functional beverages from lemongrass (Cymbopogon citratus), white ginger (Zingiber officinale Roscoe) and black tea (Camelia sinensis) were developed based on their $\alpha$-glucosidase inhibitory (AGI) activities and sensory acceptance. The AGI was evaluated using in vitro enzymatic assay, while sensory acceptance was tested using affective sensory tests. The evaluation of their aqueous extracts showed that dried lemongrass and ginger possessed higher extraction yield $(3.4 \%, 2.7 \%$, respectively), though not necessarily accompanied with a better AGI activity ( $\mathrm{IC}_{50} 24.50 \mathrm{mg} / \mathrm{mL}, \mathrm{IC}_{50} 16.61 \mathrm{mg} / \mathrm{mL}$ ) than the fresh lemongrass and ginger $\left(2.1 \%, 1.8 \%, \mathrm{IC}_{50} 17.93 \mathrm{mg} / \mathrm{ml}, \mathrm{IC}_{50}>47.00 \mathrm{mg} / \mathrm{mL}\right.$, respectively). Meanwhile, the evaluation of the combined extract showed additive and synergistic effects. The extract combination formula was selected based on the sensory acceptance, resulting in the beverages containing $4.29 \mathrm{mg} / \mathrm{mL}$ of lemongrass, $0.71 \mathrm{mg} / \mathrm{mL}$ of ginger, and $1.05 \mathrm{mg} / \mathrm{mL}$ of black tea with a total phenolic content of $636.45 \mathrm{mg} / \mathrm{L}$ Gallic Acid Equivalent (GAE). The selected formula showed the stability of AGI activity andthe $\mathrm{pH}$ value at $4{ }^{\circ} \mathrm{C}$ were in accordance with the growth of microbial count that was lower than those stored at $25{ }^{\circ} \mathrm{C}$ in a 50-day period. Changes in color and ${ }^{\circ} \mathrm{Brix}$ value were not significantly observed in the samples stored at $25{ }^{\circ} \mathrm{C}$ and $4{ }^{\circ} \mathrm{C}$. Lime juice was selected as the additional flavoring agent, which could increase both the palatability and AGI activity of the beverages.
\end{abstract}

Keywords: alpha glucosidase inhibitor; diabetes; functional food; ginger; lemongrass.

\section{INTRODUCTION}

International Diabetes Federation (2019) reported Indonesia as the $7^{\text {th }}$ country with the highest diabetes patients in the world, and $90 \%$ of them are suffering type 2 diabetes mellitus (T2DM). The management of T2DM employed $\alpha$-glucosidase inhibitors (AGI) as one of the safest oral antidiabetic agents (Mun'im et al., 2013), which becomes the focus of this paper. They work by inhibiting the enzyme $\alpha$-glucosidase, which delays the passage of carbohydrates into the bloodstream, thus decreases the postprandial blood glucose level (Amiri et al., 2015). The AGI can naturally be found in many Indonesian plants, such as lemongrass (Gunawan-Puteri et al., 2017), ginger (Oboh et al., 2010), and black tea (Christianty et al.,2016),

Lemongrass (Cymbopogon citratus) is a prevalent Indonesian food ingredient, which is commonly used in tea and traditional concoctions (Togatorop et al., 2015). The antihyperglycemic activity of spray dried aqueous extract of lemongrass was confirmed through both in-vitro and in-vivo methods (GunawanPuteri et al., 2018). Several studies were conducted to observe the impacts of pretreatment, such as washing and various drying techniques to the AGI activity of lemongrass extract (Widiputri et al., 2017). 
Various parameters including the extraction solvents, temperature, and post-treatment were found to affect the activities of AGI in lemongrass (Gunawan-Puteri et al., 2017). Lemongrass exhibited anti-hyperglycemic activity in the form of various products, such as tea (Garba et al., 2020) and essential oils (Bharti et al., 2013). The hypoglycemic effect of plant extracts was studied to be correlated with the presence of tannic acids and polyphenols, which stimulates glucosetransport activity and inhibits the alphaglucosidase enzyme while promoting pancreatic insulin release, respectively (Ademuwiya et al., 2015). Powdered and aqueous extract of lemongrass added in yogurt and ice cream showed AGI activity. However, the heating and cooling processes decreased the inhibiting activity of these models (Santoso et al., 2018). In addition, an industrial approach to lemongrass extract as an antidiabetic food ingredient was also studied (Widiputri et al., 2018).

The use of white ginger (Zingiber officinale Roscoe) is popular since the medieval period. It is not only used for culinary purposes, but also studied to exhibit the anti-inflammatory, cholesterol-lowering, anti-thrombotic, and antiemetic properties (Abeysekera et al., 2007). The observation of the anti-hyperglycemia of white ginger extract was also conducted through in-vitro and invivo methods. The white and red ginger aqueous extracts indicated an inhibition to the carbohydrate metabolism enzymes such as $\alpha$ glucosidase and $\alpha$-amylase (Oboh et al., 2010). Both ethanolic extract of ginger and dried ginger powder consumed by diabetic human patients showed potential for the hyperglycemia treatment (Andallu et al., 2003; $\mathrm{Yu}$ et al, 2011). The antidiabetic activity of white ginger was studied as the effect of chemical compounds such as gingerol and shogaol (Singh et al., 2009; Priyarani et al., 2011).

Tea (Camellia sinensis) is available in various varieties and types based on the degree of fermentation, such as unfermented (green tea), semi-fermented (oolong tea), and fully fermented (black tea) types of tea. Among these three types, black tea is the most widely consumed and produced worldwide (Striegel et al., 2015). Tea has been acknowledged for its medicinal properties, such as preventing heart disease, cancer, and diabetes mellitus (Gardner et al., 2007; Christianty et al., 2016). Both catechins and theaflavins in tea are believed to possess AGI effect. The interaction between flavonoids and yeast alphaglucosidases was studied and showed that the hydroxyl groups play a major role in the inhibition of such enzymes by binding them to their active sites (Christianty et al., 2016). A study comparing black tea, oolong tea, and green tea discovered that black tea possesses the highest AGI activity of all (Lee et al., 2010).

Different from black tea, which is usually found in a form of dried loose leaf or tea bag, lemongrass and ginger as common herbs and spices can be easily found in fresh and dried forms. For that reason, commercial dried black tea leaves were used in this experiment. As for both lemongrass and ginger, it is important to compare which form resulted in more efficiency. Due to the importance of comparing which form resulted in more efficiency for both the lemongrass and ginger.

The combination of these ingredients is expected to lower the postprandial blood glucose level, in order to be served as a functional beverage. However, when several ingredients are combined, some interactions might happen, i.e., the antagonistic, synergistic or additive effects (Wang et al., 2011). Addition of herbs to the tea was also found to enhance the palatability and consumer acceptability of a beverage (Malongane et al., 2017). A combination of lemongrass and ginger essential oils presented a better antimicrobial property (Sahamastuti et al., 2019). Synergistic effect in lowering postprandial blood glucose was also found in the combination of green tea, ginger, and cinnamon extracts (Azzeh, 2013). On the other hand, the mixtures of lemongrass and ginger aqueous extract exhibited lower antioxidant activity compared to the single plant extract (Poh et al., 2018). Thus, it is important to 
analyze the combination effects. Aside from their interaction effects, suitable formulation of such beverages remains unidentified.

One important parameter in developing functional beverages is its function stability against storage, especially when the product contains degradable bioactive compounds. To ensure that the product is in optimum condition by the time it reaches the consumers, a shelf-life testing is conducted to provide an insight into the possible chemical changes of the product during the storage.

In this study, the AGI activities of lemongrass and ginger in fresh and dried form were compared and selected for the beverage formulation. Essentially, the alteration of AGI affected by combination, formulation, flavorings, and storage were observed.

\section{METHODS}

Materials

The formulation materials consisted of lemongrass (CV. Sekar Utami, Indonesia), white ginger (CV. Sekar Utami, Indonesia), Camellia sinensis var. sinensis and Camellia sinensis var. assamica (Laresolo, Indonesia), lime (Tangerang Selatan, Indonesia), pandanus leaves (Tangerang Selatan, Indonesia), cinnamon powder (Koepoe-koepoe, Indonesia), sodium benzoate (Purox® S Grains, Holland), Stevia (Tropicana Slim, Indonesia), and nondairy creamer Fiber Crème (Ellenka, Indonesia).

Analytical grade chemicals were used in this study, including sucrose (Merck, Germany), maltose (Merck, Germany), potassium phosphate (Merck, Germany), potassium dihydrogen phosphate (Sinopharm Chemical Reagent Co., Shanghai), dimethyl sulfoxide (DMSO) (Merck, Germany), ethylenediaminetetraacetic acid (EDTA) (Merck, Germany), Triton-X100 (Merck, Germany), rat intestinal acetone powder (Sigma-

Aldrich,Germany),tris(hydroxylmethyl) aminomethane (Merck, Germany), hydrochloric acid 37\% (HCl) (PT. Smartlab, Indonesia), glucose kit (Wako Pure Chem. Co., Japan), Folin's reagent (Merck,
Germany), sodium carbonate (Merck, Germany), gallic acid (Merck, Germany), and plate count agar (Merck, Germany).

\section{Extracts preparation}

First, fresh lemongrass and ginger were washed, cut, and oven-dried at $40{ }^{\circ} \mathrm{C}$ for 72 and $48 \mathrm{~h}$, respectively, until the moisture content was less than $10 \%$. The extraction for both lemongrass and ginger was done at optimum conditions as described in GunawanPuteri et al., (2017). The lemongrass and ginger were macerated for $40 \mathrm{~min}$ at $70^{\circ} \mathrm{C}$ with continuousstirring, and the ratios of them to the water were $3: 10(\mathrm{w} / \mathrm{v})$ and $2: 10(\mathrm{w} / \mathrm{v})$, respectively. Dried black tea leaves were directly maceratedin hot water at $80^{\circ} \mathrm{C}$ for 3 min, with the extraction ratio of 1:100 (w/v). All extractswere filtered using Whatman filter no. 1 and centrifuged for $20 \mathrm{~min}$ in $6000 \mathrm{rpm}$ at $4^{\circ} \mathrm{C}$. The obtained supernatant was freezedried at $-40{ }^{\circ} \mathrm{C}$ for $\pm 16 \mathrm{~h}$. Freeze-dried samples were dissolved in DMSO 50\% until the desired concentration was obtained and stored in a glass bottle at $4^{\circ} \mathrm{C}$. The extracts underwent rat intestinal sucrase and maltase inhibitory activity assays.

In the evaluation of the effect of extract combination to the AGI activities, black tea, dried lemongrass and dried ginger extracts were diluted into their $\mathrm{IC}_{50}$ concentration and combined with the same ratio. $\mathrm{C} 1$ consisted of lemongrass and black tea $(1: 1 \mathrm{v} / \mathrm{v}), \mathrm{C} 2$ ginger and black tea in the ratio of $1: 1 \mathrm{v} / \mathrm{v}$, whereas, C 3 contained lemongrass and ginger $(1: 1 \mathrm{v} / \mathrm{v})$, and $\mathrm{C} 4$ was a combination of all ingredients $(1: 1: 1 \mathrm{v} / \mathrm{v})$. Then, the rat intestinal sucrase and maltase inhibitory activity assays were conducted to the extract combinations.

\section{Prototype beverage preparation}

The formulation of prototype beverage was made considering the effective dose based on the previous in-vivo studies using rats conducted by Ademuwiya et al. (2015) and Abdulrazaq et al. (2012). The human effective dose was calculated as presented in Table 1. 
Table 1. Human effective dose calculation

\begin{tabular}{ccccc}
\hline Sample & $\begin{array}{c}\text { Rat Effective Dose } \\
(\mathrm{mg} / \mathrm{kg} \mathrm{BW})\end{array}$ & $\begin{array}{c}\text { Conversion } \\
\text { Ratio }\end{array}$ & $\begin{array}{c}\text { Human Effective Dose } \\
(\mathrm{mg} / \mathrm{kg} \mathrm{BW})\end{array}$ & $\begin{array}{c}\text { Human Effective Dose } \\
(\mathrm{mg} / \text { day })^{\# \#}\end{array}$ \\
\hline Lemongrass & $200^{*}$ & $0.162^{\#}$ & 32.43 & $2,010.81$ \\
Ginger & $100^{* *}$ & & 16.22 & $1,005.41$ \\
\hline
\end{tabular}

*Ademuwiya et al., $2015^{* *}$ Abdulrazaq et al., 2012 " FDA, 2005

\#\# Assuming the average human body weight is $62 \mathrm{~kg}$ (Walpole et al., 2012)

The minimum volume of serving was calculated using the $\mathrm{IC}_{50}$ result from the rat intestinal sucrase and maltase inhibitory activity assays. The volume used in the formulation was adjusted by considering the beverage palatability. The liquid lemongrass (Total Soluble Solids/TSS $=16.7 \mathrm{mg} / \mathrm{mL}$ ), ginger $(\mathrm{TSS}=8.3 \mathrm{mg} / \mathrm{mL})$, and black tea $(\mathrm{TSS}=1.6 \mathrm{mg} / \mathrm{mL})$ extracts were combined into nine formulations. The ratios of lemongrass and ginger extracts were varied as follows: 1:3 for 13-A, B, C, 1:1 for 11-A, B, C, and 3:1 for 31-A, B, C samples. Black tea was used to fill up the remaining volume and the samples were served into three common serving sizes for RTD tea products (Table 2).

Table 2. Prototype formulation

\begin{tabular}{|c|c|c|c|c|c|c|}
\hline Sample & $\begin{array}{l}\text { Lemongrass } \\
\text { Extract (mL) }\end{array}$ & $\begin{array}{l}\text { Lemongrass } \\
\text { Concentration } \\
(\mathrm{mg} / \mathrm{mL})\end{array}$ & $\begin{array}{l}\text { Ginger } \\
\text { Extract } \\
(\mathrm{mL})\end{array}$ & $\begin{array}{c}\text { Ginger } \\
\text { Concentration } \\
(\mathrm{mg} / \mathrm{mL})\end{array}$ & $\begin{array}{c}\text { Black Tea } \\
\text { Concentration } \\
(\mathrm{mg} / \mathrm{mL})\end{array}$ & $\begin{array}{c}\text { Serving } \\
\text { Size }(m L)\end{array}$ \\
\hline $13-\mathrm{A}$ & \multirow{3}{*}{30} & 1.43 & \multirow{3}{*}{90} & 2.13 & 1.05 & 350 \\
\hline $13-\mathrm{B}$ & & 1.67 & & 2.49 & 0.96 & 300 \\
\hline $13-\mathrm{C}$ & & 2.00 & & 2.99 & 0.83 & 250 \\
\hline $11-\mathrm{A}$ & \multirow{3}{*}{60} & 2.86 & \multirow{3}{*}{60} & 1.42 & 1.05 & 350 \\
\hline $11-\mathrm{B}$ & & 3.34 & & 1.66 & 0.96 & 300 \\
\hline $11-\mathrm{C}$ & & 4.01 & & 1.99 & 0.83 & 250 \\
\hline $31-\mathrm{A}$ & \multirow{3}{*}{90} & 4.29 & \multirow{3}{*}{30} & 0.71 & 1.05 & 350 \\
\hline $31-\mathrm{B}$ & & 5.01 & & 0.83 & 0.96 & 300 \\
\hline $31-\mathrm{C}$ & & 6.01 & & 1.00 & 0.83 & 250 \\
\hline
\end{tabular}

Each prototype was mixed with sodium benzoate $1 \%$ and sweetener (stevia, sorbitol and erythritol), pasteurized $\left(75^{\circ} \mathrm{C}, 1 \mathrm{~min}\right)$, and hot-filled into autoclaved glass bottles. Focus group discussion, followed by hedonic and forced ranking tests were conducted to evaluate the sensory acceptance of the formulations. Prototype with the highest acceptance was further improved with the addition of flavorings: $\mathrm{F} 1 \quad(+0.4 \%$ pandanus leaves, $2 \%$ non-dairy creamer $), \mathrm{F} 2 \quad(+0.1 \%$ cinnamon powder), and F3 (+1\% lime juice). The AGI activities and sensory acceptance of these three improved prototypes were evaluated using forced ranking test.

\section{Rat intestinal sucrase and maltase inhibitory activity assay}

The evaluation of $\alpha$-glucosidase inhibitors (AGI) activity was determined using rat intestinal glucosidase inhibitory assay, adjusting to the method of Arsiningtyas et al. (2015) and Gunawan-Puteri and Kawabata (2010) with a minor modification. Rat intestinal acetone powder was dissolved in potassium phosphate buffer $(0.1 \mathrm{M}, \mathrm{pH} 7)$ and the mixture was homogenized in cold mortar. The mixture was centrifuged for $60 \mathrm{~min}$ $\left(11,000 \mathrm{rpm}, 4^{\circ} \mathrm{C}\right)$. The precipitation obtained from the centrifugation was solubilized in the same buffer containing 1\% Triton-X100 and centrifuged for the second time for $90 \mathrm{~min}$ $\left(11,000 \mathrm{rpm}, 4^{\circ} \mathrm{C}\right)$.

Sucrose $56 \mathrm{mM}$ in phosphate buffer $(200 \mu \mathrm{L})$ was added to the sample and control test tubes while $0.1 \mathrm{M}$ potassium phosphate buffer $(400 \mu \mathrm{L})$ was added to the sample blank 
and control blank test tubes. Working samples diluted in DMSO 50\% $(100 \mu \mathrm{L})$ were added to the sample and sample blank test tubes. Subsequently, DMSO 50\% $(100 \mu \mathrm{L})$ was added to the control and control blank test tubes. The reaction began when crude rat intestinal glucosidase $(200 \mu \mathrm{L})$ was added to the sample and control test tubes. Procedures for the assay of rat intestinal maltase inhibitory activity were basically similar, except for replacing sucrose $56 \mathrm{mM}$ as the substrate with maltose $3.5 \mathrm{mM}$ in phosphate buffer, and reducing the amount of crude enzyme from $200 \mu \mathrm{L}$ to $50 \mu \mathrm{L}$. The reaction was carried out at $37^{\circ} \mathrm{C}$ for $15 \mathrm{~min}$ and stopped by adding Tris- $\mathrm{HCl}$ buffer $(2 \mathrm{M}, \mathrm{pH} 9$, $750 \mu \mathrm{L})$.

The mixtures were then delivered through a column that had been filled with $1 \mathrm{~g}$ of aluminum oxide 60 . Around $50 \mu \mathrm{L}$ portion of each mixture was inserted into a 96-wells microplate, and glucose kit solution $(200 \mathrm{~mL})$ was added which turned pink when it had reacted with glucose. The incubation was done in an incubator at $37{ }^{\circ} \mathrm{C}$ for $15 \mathrm{~min}$. The absorbance was read using a microplate reader at $492 \mathrm{~nm}$ wavelength. The inhibition activity was determined using the following formula.

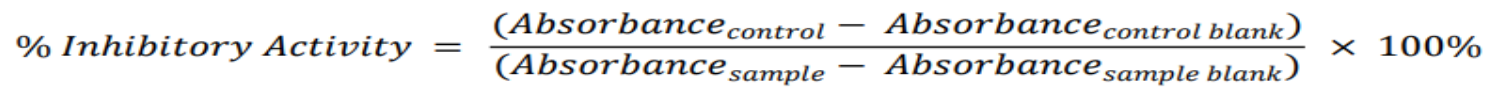

\section{Equation 1. Inhibitory activity calculation}

The experiments were conducted twice for each concentration and the resulting sucrase and maltase inhibitory activities were plotted in a curve against the concentration to derive the linear regression mathematical formula. The data were presented as $\mathrm{IC}_{50}$, which was defined as a sample concentration that inhibited $50 \%$ of sucrose and maltose hydrolysis into glucose and fructose or to glucose and glucose in the presence of crude extract of rat intestinal acetone powder.

\section{Total polyphenol analysis}

Total polyphenol was determined using Folin's Ciocalteu reagent with gallic acid (10 ppm, 25 ppm, 50 ppm, 75 ppm, 100 ppm) as the standard. The working samples were made into a 10-fold dilution, and a portion of them $(1 \mathrm{~mL})$ were added into a test tube. Folin's Ciocalteu $10 \%(5 \mathrm{~mL})$ was added into the test tube, and it was incubated for 3-8 minutes. The next step was adding sodium carbonate $7.5 \%$ (4 mL). Then, the mixture was homogenized using a vortex and incubated in a dark place for $2 \mathrm{~h}$. The absorbance was measured at $740 \mathrm{~nm}$ wavelength. Total polyphenol was measured using the following formula, where $\mathrm{W}$ stands for sample weight $(\mathrm{g})$, $a$ stands for the intercept of standard linearity, and $b$ stands for slope of standard linearity.

$$
\text { Total Polyphenol }=\frac{[\text { Absorbance }-a] / b \times 100}{W}
$$

Equation 2. Total polyphenol calculation

\section{Sensory evaluation}

A focus group discussion (n panelists $=$ 9) was conducted to the nine prototypes (Table 2) to determine the reactions that can be expected from a larger population, and to obtain qualitative data of different formulations. The acquired information was the descriptions of sensory attributes (aroma, color, flavor, and aftertaste) and the acceptance of each formula (like or dislike).
Three formulations with the highest acceptance rate were analyzed using hedonic and forced ranking tests, with larger population (n panelist $=30$ ). Hedonic test was grounded on the overall acceptance of the product with the degree of preference using 9point hedonic test where 1 indicates "like extremely" and 9 indicates "dislike extremely". Forced ranking test was conducted following the hedonic test. The panelists were asked to 
rank the samples from 1 to 3 based on their preferences, in which 1 indicates the most preferred sample, and 3 indicates the least preferred sample. The formula with the highest acceptance rate was further improved using flavorings and evaluated for the forced ranking test using larger population ( $\mathrm{n}$ panelist $=$ 94).

The results of the sensory affective tests were expressed as mean \pm standard deviation (SD). The data were analyzed using Friedman's and Wilcoxon test. The 0.05 probability level was used for all statistical analysis in this research, and p-value >0.05 was considered not statistically significant.

\section{Shelf-life analysis}

The selected formulation was stored at 4 and $25{ }^{\circ} \mathrm{C}$ for 50 days and its shelf-life was analyzed by observing the AGI activity as described above, ${ }^{\circ}$ Brix value using refractometer, $\mathrm{pH}$ value using $\mathrm{pH}$ meter (Horiba, Japan), color intensity using colorimeter (PCE, Germany), and total microbial count. The colors were represented as $\mathrm{L}$, $\mathrm{a}$, and $\mathrm{b}$ values. Total microbial count was conducted using total plate count method. The sample was prepared into 4 dilutions (from $10^{-1}$ to $10^{-4}$ ) using saline solution. Around $1 \mathrm{ml}$ of sample from each dilution was pipetted aseptically to the sterilized petri dishes. Then, about $12-15 \mathrm{ml}$ of PCA $\left( \pm 45^{\circ}\right.$ C) was poured, and the petri dishes were sealed using Parafilm M. The aerobic mesophilic bacteria growth was recorded after the sample was incubated in proper culturing environmentfor 48 hours at the temperature of $37 \pm 1^{\circ} \mathrm{C}$. The observed colonies ranging from 25 to 250 were recorded.

\section{Addition of flavoring agents}

Three flavors were developed based on the Indonesian tea recipes to increase customer acceptability, divided into sample $\mathrm{F} 1(+0.4 \%$ pandanus Leaves, $2 \%$ non-dairy creamer), F2 ( $+0.1 \%$ cinnamon powder), and F3 ( $+1 \%$ lime juice). Rat intestinal sucrase and maltase inhibitory activity assay and forced ranking test $(n=94)$ were conducted to the samples.

\section{RESULTS AND DISCUSSION Determination of raw ingredients}

Drying can significantly reduce food moisture content not only to prolong its shelf life, but also to decrease product mass and volume to ease its transportation and storage. However, the drying process may also diminish the product quality, such as losses of nutrients and functionality (Singh and Heldman, 2014). In this experiment, dried and fresh lemongrass and ginger were compared in terms of practicality, storage stability, and AGI activity. Dried form, as mentioned earlier, possesses a better practicality and storage stability. Inhibitory activity assay conducted on dried lemongrass (DC) resulted in $\mathrm{IC}_{50}$ of $24.50 \mathrm{mg} / \mathrm{mL}$ (yield $=3.4 \%$ ), while fresh lemongrass (FC) produced an $\mathrm{IC}_{50}$ of 17.93 $\mathrm{mg} / \mathrm{mL}$ (yield $=2.1 \%$ ). In terms of AGI activity, both DC and FC possessed similar figures. Therefore, since DC is more practical and stable than FC, it was selected as the ingredient of RTD. On the other hand, dried ginger (DZ) was found to possess much higher AGI activity ( $\left.\mathrm{IC}_{50} 16.61 \mathrm{mg} / \mathrm{mL}\right)$ than the fresh extract (FZ) $\left(\mathrm{IC}_{50}>47.00 \mathrm{mg} / \mathrm{mL}\right)$. The yield of DZ (2.7\%) extract was also higher than FZ (1.8\%). As a result, DZ was selected as the raw ingredient.

The AGI activity of DZ that was higher than those of FZ was predicted to be affected by the fact that drying ginger caused the alteration of one active compound to another structure that is responsible for AGI activity. In this case, it was from gingerols to shogaols (Figure 1). Gingerols are the major constituents in ginger. According to Bhattarai et al., (2001), gingerols have $\beta$-hydroxy keto functional group in the structure, which makes them thermally unstable. When exposed to drying, dehydration occurs, which removes the hydroxyl group in gingerols, thus forming shogaol. The presence of double bond in $\alpha, \beta$ unsaturated carbonyl in the chemical structure of shogaol identifies shogaol as a possible nucleophile that can donate electrons and form a new covalent bond when there is water addition in the extraction process. Therefore, it was predicted that the reason for a higher sucrase inhibitory activity in the ginger is due 
to shogaol that acts as an inhibitor towards sucrase. As a result, sucrase is not able to hydrolyze sucrose into glucose and fructose, thus presenting an inhibition activity.

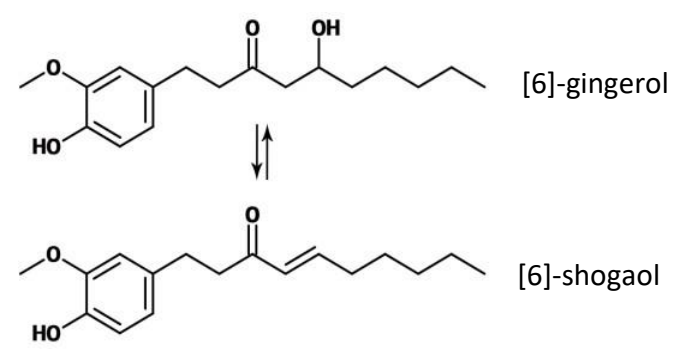

Figure 1. Structure of [6]-gingerol (A) and [6]-shogaol [B]

The synergistic/antagonistic effects in black tea, lemongrass and ginger were assessed. The extracts were prepared into their
$\mathrm{I} C_{50}$ concentration, and combined as presented in Table 3.

Table 3. Effects of Extracts Combination

\begin{tabular}{ccc}
\hline & \multicolumn{2}{c}{ \% Inhibitory Activity } \\
\cline { 2 - 3 } & Sumple* & Maltase \\
\cline { 2 - 3 } C1 $\left(\mathrm{DC}^{1}+\mathrm{BT}^{2}, 1: 1(\mathrm{v} / \mathrm{v})\right)$ & $56.87 \pm 5.67^{\mathrm{a}, \mathrm{b}}$ & $42.52 \pm 4.53^{\mathrm{c}}$ \\
\hline $\mathbf{C 2}(\mathrm{DZ}+\mathrm{BT}, 1: 1(\mathrm{v} / \mathrm{v}))$ & $55.15 \pm 3.51^{\mathrm{a}, \mathrm{b}}$ & $61.76 \pm 4.58^{\mathrm{d}}$ \\
\hline $\mathbf{C 3}(\mathrm{DC}+\mathrm{DZ}, 1: 1(\mathrm{v} / \mathrm{v}))$ & $61.74 \pm 0.94^{\mathrm{a}}$ & $57.77 \pm 6.06^{\mathrm{d}}$ \\
\hline $\mathbf{C 4}(\mathrm{DC}+\mathrm{DZ}+\mathrm{BT}, 1: 1: 1(\mathrm{v} / \mathrm{v} / \mathrm{v}))$ & $51.62 \pm 1.75^{\mathrm{b}}$ & $63.03 \pm 2.29^{\mathrm{d}}$
\end{tabular}

${ }^{*}$ All extracts were prepared in their IC50 concentration as follows: ${ }^{1}$ Sucrase IC $_{50}: 24.5 \mathrm{mg} / \mathrm{mL} ; \mathrm{Maltase} \mathrm{IC}_{50}$ : $17.5 \mathrm{mg} / \mathrm{mL},{ }^{2}$ Sucrase IC I0 $_{50} 12.53 \mathrm{mg} / \mathrm{mL}$; Maltase IC $50: 1.95 \mathrm{mg} / \mathrm{mL},{ }^{3}$ Sucrase IC I0 $_{50}: 19.61 \mathrm{mg} / \mathrm{mL}$; Maltase IC 50 : $13.38 \mathrm{mg} / \mathrm{mL}$. Lowercase letters $(a, b, c, d)$ indicate significant differences between treatments $(\mathrm{p}<0.05)$

The results showed that all combinations did not confirm the synergistic/antagonistic effect on the sucrase nor maltase inhibitory activities. This may occur if the compounds in each ingredient do not interact in any way. However, it can be concluded that they possess additive effects if combined; not only in terms of maltase inhibitory activity, but also in terms of palatability (Togatorop et al., 2015). Since the combination of extract did not adversely affect the AGI activities, the formulation was further selected based on the sensory properties and acceptance. Since tea has been associated with full-bodied, rich, and viscous sensory properties (Ukers, 1935; Ellis, 2002), C4 formula was selected. Furthermore, tea costs cheaper than lemongrass and ginger, thus it reduces the beverage production cost. Then, focus group discussion ( $\mathrm{n}$ panelists $=9$ ) was conducted to the nine formulations (Table 2) and it resulted in 11-B, 11-A, and 31-A as the three most preferred formulas (Table 4). 
Table 4. Focus group discussion result ranked by preferences

\begin{tabular}{|c|c|c|c|c|c|}
\hline Formula & Aroma & Appearance & Flavor & Aftertaste & $\begin{array}{l}\text { Preference } \\
(\%)\end{array}$ \\
\hline 11-B & Strong lemongrass & $\begin{array}{l}\text { Cloudy, dark- } \\
\text { colored }\end{array}$ & $\begin{array}{l}\text { Tea-like, slightly spicy, bitter, } \\
\text { sweet }\end{array}$ & $\begin{array}{l}\text { Slightly spicy, } \\
\text { sweet }\end{array}$ & 100 \\
\hline $11-A$ & $\begin{array}{l}\text { Lemongrass, } \\
\text { ginger }\end{array}$ & $\begin{array}{l}\text { Dark-colored, } \\
\text { tea-like }\end{array}$ & $\begin{array}{l}\text { Tea-like, sweet, lemongrass, } \\
\text { slightly spicy, slightly bitter, } \\
\text { sweet }\end{array}$ & $\begin{array}{l}\text { Slightly spicy, } \\
\text { sweet }\end{array}$ & 77.8 \\
\hline $31-A$ & Lemongrass & $\begin{array}{l}\text { Dark-colored, } \\
\text { tea-like }\end{array}$ & $\begin{array}{l}\text { Tea-like, slightly } \\
\text { slightly bitter, sweet }\end{array}$ & $\begin{array}{l}\text { Slightly spicy, } \\
\text { sweet }\end{array}$ & 77.8 \\
\hline $11-\mathrm{C}$ & Strong lemongrass & Cloudy, tea-like & $\begin{array}{l}\text { Tea-like, sweet, slightly } \\
\text { spicy, bitter, slightly sweet, } \\
\text { slightly astringent }\end{array}$ & $\begin{array}{l}\text { Spicy, slightly } \\
\text { astringent, } \\
\text { slightly bitter, } \\
\text { sweet }\end{array}$ & 66.7 \\
\hline $13-\mathrm{C}$ & Strong ginger & $\begin{array}{l}\text { Cloudy, } \\
\text { concoction-like }\end{array}$ & $\begin{array}{l}\text { Concoction-like, very spicy, } \\
\text { very bitter, slightly sweet }\end{array}$ & $\begin{array}{l}\text { Very spicy, } \\
\text { astringent, sweet }\end{array}$ & 11.1 \\
\hline $13-\mathrm{B}$ & $\begin{array}{l}\text { Concoction-like, } \\
\text { ginger }\end{array}$ & Cloudy, tea-like & $\begin{array}{l}\text { Concoction-like, very spicy, } \\
\text { very bitter, slightly sweet }\end{array}$ & $\begin{array}{l}\text { Very spicy, } \\
\text { bitter }\end{array}$ & 0 \\
\hline $13-\mathrm{A}$ & $\begin{array}{l}\text { Strong ginger, light } \\
\text { lemongrass }\end{array}$ & Cloudy & Concoction-like, spicy & Spicy & 0 \\
\hline $31-\mathrm{C}$ & Strong lemongrass & Cloudy, tea-like & $\begin{array}{l}\text { Tea-like, strong lemongrass, } \\
\text { very bitter, sweet }\end{array}$ & $\begin{array}{l}\text { Slightly spicy, } \\
\text { bitter, sweet }\end{array}$ & 0 \\
\hline $31-\mathrm{B}$ & $\begin{array}{l}\text { Strong lemongrass, } \\
\text { ginger }\end{array}$ & Cloudy & 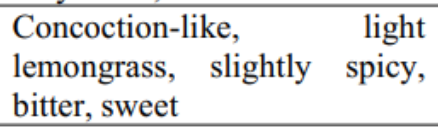 & $\begin{array}{l}\text { Slightly } \\
\text { sweet }\end{array}$ & 0 \\
\hline
\end{tabular}

The three most preferred formulas were further tested to a larger population $(n=30)$ to select the best formula using a 9-scale hedonic and confirmed by a ranking test (Table 5). The selected formula in both tests was in agreement with each other, resulting in "like moderately" to "like slightly" for 31-A formula. Therefore, formula 31-A was used for the further research.

Table 5. Hedonic test results

\begin{tabular}{cccc}
\hline Sample & $\begin{array}{c}\text { Overall Acceptance } \\
\text { Mean }^{*}\end{array}$ & Overall Acceptance & $\begin{array}{c}\text { Forced Ranking Test } \\
\text { Mean }^{* *}\end{array}$ \\
\hline $31-\mathrm{A}$ & $3.83 \pm 1.15^{\mathrm{a}}$ & $\begin{array}{c}\text { Like moderately }- \text { Like } \\
\text { slightly }\end{array}$ & $1.33 \pm 0.61^{\mathrm{c}}$ \\
\hline $11-\mathrm{A}$ & $5.16 \pm 1.64^{\mathrm{b}}$ & Neither like nor dislike & $2.23 \pm 0.73^{\mathrm{d}}$ \\
\hline $11-\mathrm{B}$ & $5.20 \pm 1.40^{\mathrm{b}}$ & Neither like nor dislike $^{* * *} 1=$ most preferable, $3=$ least preferable \\
\hline${ }^{*} 1=$ like extremely, $9=$ dislike extremely \\
Lowercase letters $(a, b, c, d)$ indicate significant differences between treatments $(\mathrm{p}<0.05)$
\end{tabular}

Antioxidant is one of the responsible chemical compounds exhibiting AGI activity. Furthermore, phenolic compounds such as monoterpenes, sesquiterpenes, and oxygenic derivatives in plant extracts were observed to possess carbohydrate hydrolyzing enzymes inhibiting activity (Jumepaeng et al., 2012). Therefore, the total polyphenol content of the selected beverage formulation 31-A was measured, which resulted in $636.45 \mathrm{mg} / \mathrm{L}$ GAE (Gallic Acid Equivalent). The total polyphenol content in this formula exceeded the Indonesian National Standard of Tea Beverage (SNI 3134:2011) with a minimum of $400 \mathrm{mg} / \mathrm{kg}$.

The overall acceptance results showed "like moderately" to "like slightly" for 31-A formula. Therefore, the flavor development was required to enhance the beverage acceptance. Based on the world-wide tea recipes, three flavor profiles were chosen: bandrek (Indonesian traditional concoction using coconut cream and pandanus leaves), cinnamon tea, and lime tea. The ranking test 
was used to determine the most preferable flavor. Moreover, their AGI activities were also taken into consideration. Flavoring agent addition affected the AGI activity of the beverage (Table 6). F1 contained non-dairy creamer made of oligosaccharides that can be degraded into simpler sugars and retarded the AGI activity of the beverage. The F2 and F3 formulations possessed higher AGI activities than the flavorless formulation. Cinnamon, as added in F2, was found to potentially possess anti-hyperglycemic activity due to the cinnamtannin B1 that affects the insulin receptors phosphorylation (Al-Samydai et al., 2018). Whereas, lime juice in F3 contains chemical compounds with antioxidant properties, such as vitamin $\mathrm{C}$, that was found to inhibit the aldose reductase enzyme. Other antioxidants in the lime juice reduced the advanced glycation end products (AGEs) formation in sorbitol-aldolase reductase pathway and affected the glucose metabolismrelated enzyme gene expression (Mawarti et al., 2018). Moreover, the addition of lime juice increased the acidity of the formula, which promoted freshness, enhanced the perception of other tastes and might prolong the shelf life of a beverage (Marcus, 2019). The ranking test showed that both F1 and F3 were more preferred than F2. However, F1 was found to have no AGI activity towards sucrase; therefore, F3 formulation was considered to be developed further.

Table 6. Effect of flavoring agents to the AGI and ranking test results

\begin{tabular}{cccc}
\hline Samples & $\begin{array}{c}\text { Sucrase Inhibitory } \\
\text { Activity (\%) }\end{array}$ & $\begin{array}{c}\text { Maltase Inhibitory } \\
\text { Activity (\%) }\end{array}$ & Ranking Test Mean \\
\hline F1 $1=$ most preferable, $3=$ least preferable, Lowercase letters $(a, b)$ indicate significant differences between \\
treatments (p<0.05)
\end{tabular}

\section{Stability of the product}

Stability of 31-A was tested in a 50-day period at $4{ }^{\circ} \mathrm{C}$ and $25{ }^{\circ} \mathrm{C}$. The results are presented in Table 7. Apparently, the samples stored at $25^{\circ} \mathrm{C}$ showed significant microbial growth compared to those stored at $4^{\circ} \mathrm{C}$. On the $5^{\text {th }}$ day of storage, microbial growth of the samples stored at $25^{\circ} \mathrm{C}$ exceeded $2.4 \mathrm{log}$ $\mathrm{CFU} / \mathrm{mL}$, while microbial growth of samples stored at $4{ }^{\circ} \mathrm{C}$ exceeded $2.4 \log \mathrm{CFU} / \mathrm{mL}$ only on the $50^{\text {th }}$ day with $2.5 \log \mathrm{CFU} / \mathrm{mL}$. The temperature-dependent stability also showed the same trend in $\mathrm{pH}$ value, in which the samples stored at $25 \circ \mathrm{C}$ showed more apparent $\mathrm{pH}$ decline (from 5.81 to 4.16) than those stored at $4{ }^{\circ} \mathrm{C}$ (final $\mathrm{pH} 4.73$ ). The ${ }^{\circ} \mathrm{Brix}$ value was stable at 2.0 throughout 50 days of storage period (no significant difference at $\mathrm{p}>0.05$ ). Higher stability of AGI activities for the samples stored at $4{ }^{\circ} \mathrm{C}$ was also coherent with the evaluation of microbial growth and $\mathrm{pH}$ value. The $L, a$, and $b$ values, which represent colors, of samples stored at both temperatures after 50 days were decreased, butnot statistically significant at $p>0.05$. The experiment showed that $4^{\circ} \mathrm{C}$ was a more preferable storage temperature for this functional beverage. However, novel preservation techniques should be studied to prolong the shelf life of the beverage. 
Table 7. Results of stability test at $4{ }^{\circ} \mathrm{C}$ and $25^{\circ} \mathrm{C}$ for 50 ays

\begin{tabular}{|c|c|c|c|c|c|c|c|c|c|c|c|c|}
\hline \multirow[b]{3}{*}{ Days } & \multirow{2}{*}{\multicolumn{2}{|c|}{$\begin{array}{c}\text { Microbial } \\
\text { Growth (log } \\
\text { CFU/mL) } \\
\end{array}$}} & & & & & \multicolumn{6}{|c|}{ Color Alteration } \\
\hline & & & \multicolumn{2}{|c|}{$\mathbf{p H}$} & \multicolumn{2}{|c|}{ Brix $^{\circ}$} & \multicolumn{2}{|c|}{$\mathbf{L}$} & \multicolumn{2}{|c|}{$\mathbf{A}$} & \multicolumn{2}{|c|}{$\mathbf{b}$} \\
\hline & $25^{\circ} \mathrm{C}$ & $4^{\circ} \mathrm{C}$ & $25^{\circ} \mathrm{C}$ & $4^{\circ} \mathrm{C}$ & $25^{\circ} \mathrm{C}$ & $4^{\circ} \mathrm{C}$ & $25^{\circ} \mathrm{C}$ & $4^{\circ} \mathrm{C}$ & $25^{\circ} \mathrm{C}$ & $4^{\circ} \mathrm{C}$ & $25^{\circ} \mathrm{C}$ & $4^{\circ} \mathrm{C}$ \\
\hline 0 & $<2.40$ & $<2.40$ & 5.81 & 5.81 & 2.05 & 2.05 & 43.85 & 43.85 & 11.18 & 11.18 & 12.33 & 12.33 \\
\hline 5 & 3.78 & $<2.40$ & 5.09 & 5.41 & 1.95 & 1.95 & 42.86 & 44.20 & 10.45 & 12.34 & 14.14 & 13.87 \\
\hline 10 & 4.04 & $<2.40$ & 4.63 & 5.16 & 2.05 & 2.05 & 43.53 & 42.69 & 11.12 & 10.55 & 13.70 & 11.13 \\
\hline 14 & 4.17 & $<2.40$ & 4.56 & 5.06 & 2.05 & 2.05 & 41.93 & 41.33 & 10.94 & 10.45 & 15.14 & 10.79 \\
\hline 20 & 4.26 & $<2.40$ & 4.53 & 5.05 & 2.00 & 1.85 & 41.16 & 40.82 & 8.90 & 8.76 & 13.42 & 8.58 \\
\hline 30 & 4.46 & $<2.40$ & 4.50 & 4.96 & 1.90 & 1.85 & 40.57 & 39.54 & 8.77 & 8.40 & 10.48 & 7.28 \\
\hline 40 & 4.60 & $<2.40$ & 4.38 & 4.89 & 1.90 & 1.85 & 39.72 & 38.93 & 8.37 & 7.55 & 6.51 & 6.01 \\
\hline 50 & 4.60 & 2.50 & 4.16 & 4.73 & 1.95 & 1.90 & 38.80 & 37.99 & 7.49 & 7.59 & 6.00 & 5.60 \\
\hline
\end{tabular}

AGI Activities

\begin{tabular}{ccccc}
\hline & \multicolumn{2}{c}{ Sucrase Inhibition (\%) } & \multicolumn{2}{c}{ Maltase Inhibition (\%) } \\
\hline Days & $\mathbf{2 5}^{\circ} \mathbf{C}$ & $\mathbf{4}^{\circ} \mathbf{C}$ & $\mathbf{2 5}^{\circ} \mathbf{C}$ & $\mathbf{4}^{\circ} \mathbf{C}$ \\
\hline 0 & 16.33 & 16.33 & 48.46 & 48.46 \\
\hline 5 & 17.99 & 14.63 & 47.97 & 45.69 \\
\hline 10 & 14.31 & 18.79 & 42.11 & 49.43 \\
\hline 14 & 15.29 & 16.41 & 39.26 & 45.19 \\
\hline 20 & 14.50 & 16.97 & 33.95 & 46.63 \\
\hline 30 & 14.56 & 14.84 & 35.00 & 42.22 \\
\hline 40 & 14.49 & 13.79 & 32.78 & 40.28 \\
\hline 50 & 8.14 & 10.52 & 24.72 & 36.04 \\
\hline
\end{tabular}

\section{CONCLUSION}

Formulation and storage of functional beverages affected the AGI activity and the study found that dried ingredients provided more extraction efficiency and practicality. Combination of dried lemongrass, ginger and black tea resulted in additive effects for maltase inhibitory activity. Formula consisted of $4.29 \mathrm{mg} / \mathrm{mL}$ lemongrass, $0.71 \mathrm{mg} / \mathrm{mL}$ ginger, and $1.05 \mathrm{mg} / \mathrm{mL}$ black tea was preferable and predominantly stable in terms of $\mathrm{pH},{ }^{\circ}$ Brix value, color, and AGI activity at $4^{\circ}$ $\mathrm{C}$ of storage. Lime juice addition could increase both the palatability and AGI activity of the beverages, hence, was selected to be further developed. In addition, more research on beverage preservation is required to prolong the shelf life.

\section{ACKNOWLEDGEMENT}

This research project was supported by a grant from the Directorate General of Resources for Science, Technology and Higher Education of the Republic of Indonesia with contract number 7/E/KPT/2019; AGMT/REC/A0012/III/2019

\section{REFERENCES}

Abdulrazaq, N.B., Cho, M.M., Win, N.N., Zaman, R., Rahman, M.T., 2012. Beneficial Effects of Ginger (Zingiber officinale) on Carbohydrate Metabolism in Streptozotocin-induced Diabetic Rats. British Journal of Nutrition, 108(7), 1194-1201.

Ademuyiwa, A.J., Olamide, O.Y., Oluwatosin, O.O., 2015. The Effects of Cymbopogon citratus (Lemongrass) on the Blood Sugar Level, Lipid Profiles and Hormonal 
Profiles of Wistar Albino Rats. Merit Research Journal of Medicine and Medical Science, 3(6), 210-216.

Al-samydai, A., Al-mamoori, F., Shehadeh, M., Hudaib, M., 2018. Anti - Diabetic Activity of Cinnamon: A Review. International Research Journal of Pharmacy and Medical Sciences, 1(5), 43-45.

Amiri, A., Azemi, M.E., Khodayar, M.J., Namjoyan, F., 2015. In Vitro $\alpha$ - Amylase and $\alpha$ - Glucosidases Inhibitory Effects of Some Plant Extracts. International Journal of Pharmacognosy and Phytochemical Research, 7(2), 315-318.

Andallu, B., Radhika, B., Suryakantham, V., 2003. Effect of Aswagandha, Ginger and Mulberry on Hyperglycemia and Hyperlipidemia. Plant Foods for Human Nutrition, 58, 1-7.

Azzeh, F.S., 2013. Synergistic Effect of Green Tea, Cinnamon and Ginger Combination on Enhancing Postprandial Blood Glucose. Pakistan Journal of Biological Sciences, 16(2), 74-79.

Bharti, S.K., Kumar, A., Prakash, O., Krishnan, S., Gupta, A.K., 2013. Essential Oil of Cymbopogon citratus Against Diabetes: Validation by In vivo Experiments and Computational Studies. Journal of Bioanalysis and Biomedicine, 5(5), 194203.

Christianty, F.M., Holidah, D., Yasmin, 2016. In vitro $\alpha$-Glucosidase Inhibitory Activity of Various Tea (Camellia sinensis L.) Extracts. Proceeding ICMHS, 104-107.

Ellis, H., 2002. Tea: Discovering, Exploring, Enjoying, p 6-60. Ryland Peters \& Small, New York.

Food and Drug Administration (FDA), 2005. Guidance for industry: estimating the maximum safe starting dose in initial clinical trials for therapeutics in adult healthy volunteers. Center for Drug Evaluation and Research (CDER), United States.
Garba, H.A., Mohammed, A., Ibrahim, M.A., Shuaibu, M.N., 2020. Effect of Lemongrass (Cymbopogon citratus Stapf) Tea in a Type 2 Diabetes Rat Model. Clynical Phytoscience, 6(19), 1-10.

Gardner, E.J., Ruxton, C.H.S., Leeds, A.R., 2007. Black tea - Helpful or Harmful? A Review of The Evidence.European Journal of Clinical Nutrition, 61(1), 3-18.

Gunawan-Puteri, M.D.P.T., Kartawiria, I.S., Widiputri, D.I., 2017. Aqueous Extraction Optimization of C. citratus for Development of Food Ingredients with Alpha Glucosidase Inhibitory. In Sukmana, I. and Ulvan, A. Integrated SciTech: Interdisciplinary Research Approach, (2), 55-61.

Gunawan-Puteri, M.D.P.T., Rustandi, F., Hendra, P., 2018. Spray Dried Aqueous Extract of Lemongrass (Cymbopogon citratus) Exhibits In-vitro and In-vivo Anti-hyperglycaemic Activities. Journal of Pharmaceutical Science and Community, 15(2), 55-61.

International Diabetes Federation. IDF Diabetes Atlas, 9th edn. Brussels, Belgium.

Jumepaeng, T., Luthria, D., Chanthai, S., 2012. The Effect of Surfactant on Headspace Single Drop Microextraction for the Determination of Some Volatile Aroma Compounds in Citronella Grass and Lemongrass Leaves by Gas Chromatography. Analytical Method, 4, 421-428.

Lee, W.K., Wong, L.L., Loo, Y.Y., Kasapis, S., Huang, D., 2010. Evaluation of different teas against starch digestibility by mammalian glycosidases. Journal of Agricultural and Food Chemistry, 58(1), 148-154.

Malongane, F., McGaw, L., Mudau, F.N., 2017. The Synergistic Potential of Various Teas, Herbs and Therapeutic Drugs in Health Improvement. Journal of the Science of Food and Agriculture, 97(14), 4679-4689. 
Marcus, J.B., 2019. Aging, Nutrition and taste: Nutrition, Food Science and Culinary Perspectives for Aging Tastefully. Academic Press, San Diego.

Mawarti, H., As'ad, Z.M., Rajin, M., 2018. Ameliorative Effect of Citrus aurantifolia and Cinnamomum burmannii Extracts on Diabetic Complications in A Hyperglycaemic Rat Model. Tropical Journal of Pharmaceutical Research, 17(5), 823829.

Mun'im, A., Katrin, Azizahwati, Andriani, A., Mahmudah, K.F., Mashita, M., 2013. Screening of $\alpha$ - Glucosidase Inhibitory Activity of Some Indonesian Medicinal Plants. International Journal of Medicinal and Aromatic Plants, 3(2), 144-150.

Oboh, G., Akinyemi, A.J., Ademiluyi, A.O., Adefegha, S.A., 2010. Inhibitory Effects of Aqueous Extracts of Two Varieties of Ginger on Some Key Enzymes Linked to Type-2 Diabetes In Vitro. Journal of Food and Nutrition Research, 49(1), 14-20.

Poh, K.H., Muhammad, N., Abdullah, N., Talip, B.A., 2018. The Evaluation of Antioxidant Activity of Individual and Mixture of Lemongrass, Curry Leaves, Turmeric and Ginger Extracts. Journal of Science and Technology, 10(2), 66-70.

Priyarani, M., Padmakumari, P., Sankarikutty, B., Cherian, O.L., Nisha, V.M., Raghu, K.G., 2011. Inhibitory Potential of GingerExtracts Against Enzymes Linked to Type 2 Diabetes, Inflammation and Induced Oxidative Stress Inhibitory. International Journal of Food Sciences and Nutrition, 62(2), 106-110.

Sahamastuti, A.A.T., Andre, Foustine, S., Sumarpo, A., Hartiadi, L.Y., 2019. Synergistic Antibacterial Activities of Ginger and Lemongrass Essential Oils as an Alternative Prevention to Food-Borne Disease. Indonesian Journal of Life Sciences, 01(02), 54-61.
Santoso, F., 2018. Application of Lemongrass (Cymbopogon citratus) as a Functional Food Ingredient with Alpha- Glucosidase Inhibitory Activity. Advance in Engineering Research, 172, 205-209.

Singh, A.B., Singh, N., Maurya, R., Kumar, A., 2009. Anti-hyperglycaemic, Lipid Lowering and Anti-oxidant Properties of [6]-gingerol in $\mathrm{db} / \mathrm{db}$ Mice. International Journal of Medicine and Medical Sciences, 1(12), 536-544.

Singh, R.P., and Heldman, D.R., 2014. Dehydration, in: Introduction to Food Engineering. Fifth Edition. Academic Press, San Diego.

Togatorop, D.M., Nainggolan, R.J., Lubis, L.M., 2015. Pengaruh Perbandingan Sari Batang Sereh dengan Sari Jahe Dan Konsentrasi Serbuk Gula Aren Terhadap Mutu Serbuk Minuman Penyegar Sereh. Jurnal Rekayasa Pangan dan Pertanian, 3(2), 157-163.

Ukers W.H.,1935. All about tea. The Tea and Coffee Trade Journal Company, New York.

Wang, S., Meckling, K.A., Marcone, M.F., Kakuda, Y., Tsao, R., 2011. Synergistic, Additive, and Antagonistic Effects of Food Mixtures on Total Antioxidant Capacities. Journal of Agricultural and Food Chemistry, 59(3), 960-968.

Widiputri, D.I., Gunawan-Puteri, M.D.P.T, Kartawiria, I.S., 2018. Benchmarking Study of Cymbopogon citratus and C. nardus for Its Development of Functional Food Ingredient for Anti-diabetic Treatment. Proceedings of the International Conference on Innovation, Enterpreneurship and Technology, 103108.

Widiputri, D.I., Mariana, N., Josopandojo, B., Gunawan-Puteri, M.D.P.T., Kartawiria, I.S., 2017. Effect of Pre-treatment Processes and Stability Testing of Lemongrass (Cymbopogon citratus) Extract on $\alpha$-Glucosidase Inhibitor (AGI) and $\alpha$-Amylase Inhibitor (AAI) activities. 
Proceedings of International Postgraduate Symposium on Food, Agriculture, and Biotechnology, pp. 10-20.
Yu, Y., Zick, S., Li, X., Zou, P., Wright, B., Sun, D., 2011. Examination of the Pharmacokinetics of Active Ingredients of Ginger in Humans. The AAPS Journal, 13(3), 417-426. 
Jurnal Farmasi Sains dan Komunitas, 2021, 18(1), 26-38 